\title{
Miranda
}

Revue pluridisciplinaire du monde anglophone /

Multidisciplinary peer-reviewed journal on the English-

speaking world

15 | 2017

Lolita at 60 / Staging American Bodies

\section{Was citizenship born with the Enlightenment?}

Developments of citizenship between Britain and France and "everyday citizenship" implications

\section{Djordje Sredanovic}

\section{OpenEdition}

\section{Journals}

\section{Electronic version}

URL: http://journals.openedition.org/miranda/11118

DOI: $10.4000 /$ miranda. 11118

ISSN: 2108-6559

Publisher

Université Toulouse - Jean Jaurès

\section{Electronic reference}

Djordje Sredanovic, "Was citizenship born with the Enlightenment?", Miranda [Online], 15 | 2017, Online since 06 October 2017, connection on 16 February 2021. URL: http://journals.openedition.org/ miranda/11118; DOI: https://doi.org/10.4000/miranda.11118

This text was automatically generated on 16 February 2021.

\section{(c) (i) (9)}

Miranda is licensed under a Creative Commons Attribution-NonCommercial-NoDerivatives 4.0 International License. 


\title{
Was citizenship born with the Enlightenment?
}

Developments of citizenship between Britain and France and "everyday citizenship" implications

\author{
Djordje Sredanovic
}

\section{Introduction}

1 Britain constitutes a peculiar case study in the area of citizenship, as British laws did not contain the word "citizenship" until the British Nationality Act of 1948. Although before that the institution ${ }^{1}$ of "subjecthood" worked in a comparable way, the 1948 Act was unique, as it made provision for six distinct citizenship statuses (most countries only have two - national and non-national), a number that further increased with the Immigration Bill of 1971. This article does not, however, aim to be simply a tale of British exceptionalism. By contrasting the British case to that of France, it aims to put forward the hypothesis that it was the successful diffusion of the French model that made most states in the world opt for the binary citizen/non-citizen or national/nonnational model, effectively rendering the alternative British approach an insular case.

In the following pages, I will first present two different lineages of contemporary citizenship, valid for the British and the French case, respectively. I will argue that it is heuristically advantageous to study British subjecthood and French nationalité and citoyenneté $^{2}$ as two different institutions. I will then present some possible explanations for the diffusion of the French model before turning to the history of British subjecthood/citizenship, showing how the latter developed in a separate fashion and how it seems to have recently shifted closer to the French model. I will conclude this article with an analysis of some aspects of everyday citizenship in Britain and France, showing the significant autonomy of everyday conceptions from the historical and institutional development of formal citizenship, as well as some effects that the formal dimension nevertheless seems to have on the notions of citizenship amongst ordinary people. 


\section{Two different lineages of citizenship?}

Academics (and others) have two common ways of describing the development of contemporary citizenship. Many start from the Magna Carta of 1215 to trace the history of English freedom and English citizenship, and present the French Revolution of 1789 as a partial transformation of the same freedoms. Others consider the Magna Carta and the successive similar British developments as privileges dealing with personal status rather than with general political norms, and point to similar institutions that existed in other countries across Europe - with the significant exception that the English institutions were the only ones to survive into the contemporary era. ${ }^{3}$ In this second lineage, the universalistic nature of the 1789 revolution is presented as without precedent. The absolute (illuminated) monarchies, with their removal of all the powers rival to the central one, anticipated the developments of the Revolution as much as the experience of British liberalism. Schnapper (58-69) is among the proponents of the first lineage, while Brubaker (1992) presents many of the aspects of the second - although the author himself indicates how this lineage can already be found in Marx.

4 For the scopes of this article, we can consider the two lineages of citizenship (which might be called "liberal" for the one starting with the Magna Carta, and "statist" for the one starting with the 1789 revolution) as the origins of two different institutions. British citizenship (subjecthood) was based on the limits placed on the power of the state, whereas French citizenship was based on the removal of all powers except those of the state. In the following pages, I will show how these approaches justify both the binary citizen/non-citizen French system, as well as the multiplication of statuses in British legislation.

\section{The French model and its diffusion}

Rogers Brubaker (1992) describes the French Revolution as the origin of both contemporary citizenship and the contemporary idea of "nation". Other scholars are more nuanced in their positions: Peter Sahlins (2003, 2004), for example, shows evidence of significant citizenship reform in France already in the 1750s, although he agrees about the "revolutionary" significance of the French experience of citizenship reform. The $18^{\text {th }}$ century has more generally been identified by both Anderson and Hobsbawm as the first period of emergence and construction of national identities, identities that both "popular" and "state" nationalisms then supraimposed to earlier historical periods.

6 Both Brubaker's analysis of the history of citizenship in France, and Torpey's analysis of the development of the passport clearly show how the revolutionary period was characterized in France by the construction of a uniform juridical and political internal space, by the abolition of internal barriers to movement, and by the definition of clear external frontiers, both in terms of territory and population. While initially open to foreigners who shared the ideals of the revolution, the nationality of Revolutionary France was rapidly well-delimited, excluding potentially hostile foreigners, as well as expatriates. 
7 This clear-cut binary division between nationals and non-nationals is the most common way in which contemporary states deal with their citizenry. How can we explain this diffusion of the French model? Napoleonic conquests had a clear role in spreading the model: citizenship spread to most of Continental Europe together with the Code civil and the metric system. Wright further argues that France was hegemonic in the military, colonial, diplomatic and cultural fields for most of the modern and early contemporary period, rendering French a lingua franca. Here, I wish to focus on a single aspect among those presented by Wright: the role of French as the diplomatic language of record between the 1714 Treaty of Rastatt and the 1919 Treaty of Versailles (in which English was added as a second language), and more generally the hegemony of France and the French language that continued in the field of diplomacy even after 1919. Torpey shows how the emergence of the global passport system coincided with this period of French hegemony. While the first states to introduce passports took upon themselves to provide identification documents to the foreigners who entered the national territory, the diffusion of the practice meant that each state was subject to external pressure to define the confines of its population and to codify who was entitled to a national passport (in addition to the on-going need to define the national population in order to facilitate mass conscription). While the internal organization of France was a politically unacceptable model for many other states during most of this period, when faced with the need to define the external organization of the state (who was and who was not a national), imitating France, which hegemonized international diplomacy, was much more acceptable.

These factors of diffusion of the French model can also explain the British exception. Other than obviously resisting Napoleon, Britain was always the "other" hegemonic state: it was powerful enough and its empire was large enough to be free from the need to imitate France in regulating nationality. Colley argues that much of the political identification the national population established with Britain was the result of intermittent wars with France between the $18^{\text {th }}$ and the $19^{\text {th }}$ century. According to Colley, the fear of foreign invasion was a strong factor in the emerging identification with the nation, together with Protestantism which, in opposition to French Catholicism, was a powerful "cement" for Great Britain (but, obviously, not for Ireland).

9 A more systematic analysis of the diffusion of the French model (and its exceptions) than the one I can offer in the limited space of this article would probably provide precious knowledge about membership in the contemporary world. At this point I will limit the discussion to some hypotheses about Latin America, which are particularly suggestive because of the role that Benedict Anderson attributes to the area in the formation of the contemporary idea of "nation". The figure of Simón Bolívar is notable in this context and not simply because of traditional portrayals that show him as inspired by Napoleon's coronation to promote the values of the French Revolution in Latin America. Bolívar also tried to consolidate his crumbling power by attempting to introduce the Code civil (which was later effectively introduced in Chile in 1855, and from there spread to most of the continent - Mirow), showing how the French institutions of the time resonated with nascent (following Anderson's hypothesis) nations.

One important context in which the binary national/non-national model was much less applied was that of the colonies - including the French ones. No colonial power renounced the opportunity to stratify the legal statuses of the populations of the 
colonies, thereby guaranteeing privileged conditions to European settlers and coopting part of the native elites into the administration of the colonies. The history and the regulations of the statuses of colonial populations are far more complicated than those of non-colonized states. Nevertheless, once the colonized territories began the decolonization process, the binary model was again the most frequently chosen, even if this sometimes meant the disenfranchisement and sometimes the expulsion of part of the population. Indeed, Manby (2009) highlights how the colonial powers usually guided the creation of new legislation concerning citizenship, pressuring for simple approaches that gave clear citizen or non-citizen status to the entire population of nascent states. Manby also adds that in some African states later legislation complicated the issue by declaring some ethnic groups native to the national territory and diminishing, if not withdrawing, citizenship from those ascribed to other ethnic groups.

\section{The British model}

Ann Dummett, an authoritative scholar of the history of the British legislation of citizenship, describes the history of British subjecthood, nationality and citizenship as "extraordinarily confused" $(2006,554)$. This is not only because of the effects of the common law system, but also because of a relative lack of interest on behalf of the British Crown and Government concerning questions of nationality, which continued for a very long period. I argue here that a further cause for this kind of development of citizenship in Britain was an institutional concept of nationality focused on the freedoms from the state rather than on a clear relationship to the state itself.

British nationality has been governed by specific precedents for most of its history: court judgements, such as Calvin's Case (1608) defined subjecthood as linked to birth having taken place on the territory of the kingdom (provided the parents were not "enemy" aliens or foreign diplomatic personnel) and kept in case of emigration. ${ }^{4}$ Such a way of defining subjecthood was not much different from what subjecthood had meant in France up to the French Revolution: in both cases those effectively concerned with subjecthood were mostly potential land inheritors, as well as merchants interested in avoiding limitations imposed on foreigners (see also Sahlins 2003, 2004). It was only with the 1789 revolution and the creation of an institution based on a clear political definition of the population of the state that a different kind of citizenship appeared and began spreading outside of France. British subjecthood, on the other hand, remained less defined and centred on the relationship of the individual to the monarch. Dummett and Nicol (1990) show how from 1608 to 1948 British subjecthood remained based on precedent and on sporadic legislative interventions that mostly recognized the precedents. Being born in the territories of the Crown meant becoming subjects for a significant part of the population. Obviously, vast exceptions existed for several groups: non-Protestants, women (and in particular married women), most of the colonized populations, black victims of slavery being the one population to lack any juridical personality. The limitation to the subjecthood of non-Protestants was finally lifted during the $19^{\text {th }}$ century, with the abolition of religious oaths as part of the naturalization process ${ }^{5}$; juridical discrimination against women was abolished during the general shift to citizenship equality of the late $20^{\text {th }}$ century (see Knop 2001). On the other hand, large parts of the colonial populations were continuously kept confined to 
lesser juridical statuses; indeed, some of the measures taken in the second half of the $20^{\text {th }}$ century can be interpreted as echoing the same discriminations existing in this period against colonial populations (see the next paragraph). Even for the (large) discriminated populations, some lesser or dependent juridical status existed, all descending from some form of recognized relationship with the Crown. Banerjee for example shows how Indians relied on the 1858 proclamation of Queen Victoria, establishing direct crown sovereignty over India, to claim Imperial subjecthood and, indeed, citizenship. She also highlights how one of the main uses of this claim was to challenge the restrictions to settlement in the "white dominions". At the same time the Empire had a significant influence on several institutional and social aspects of Britain. Thompson observes for example how the debate about the extension of voting rights (including women's voting rights) and about the autonomy of Ireland were influenced by the presence of institutional solutions that were often more progressive in other parts of the Empire - including mostly white dominions, but also Jamaica.

Obviously, the institution of British subjecthood cannot be explained through the relative power of the Crown. For most of the period concerned, the British monarchs exerted less power over the British state than most of the monarchs on the Continent held over their states. Nor can this be explained by proposing that Britain was simply being backwards in terms of moving toward contemporary citizenship. While never completely defined in its external dimensions, the internal nature (the rights) of British subjecthood became progressively similar to what we refer to as "citizenship" today. For most of the period in question, British subjects (again, those outside the colonies) were more similar in their political roles to French citizens than they were to the nationals of the other Continental states. Moreover, there were other states in which the legislation on nationality referred to the relationship of the individual with the Crown, even if it was increasingly the relationship with the metropolitan state (colonies always being a more complex context) that featured at the centre of nationality and citizenship (see for example Donati, in particular 69-94).

Dummett and Nicol $(1990,82)$ underline how, after the late $18^{\text {th }}$ century, British citizenship was set apart from most other cases by its lack of systematicity, but not necessarily by its lack of justice. Again, British citizenship was a different kind of institution, rather than simply being backwards. The authors argue that juridical factors, such as the rule of precedent, and the lack of a written Constitution (in addition to the lack of a popular revolution that could introduce a written Constitution) were behind these developments. I wish to add that the different nature of the citizenship institutions in Britain also played a role. In a context that saw citizenship primarily defined by the existence of political spaces relatively free from the state, the codifying of formal belonging to the state was far less urgent than in contexts where citizenship and politics were mostly exercised through the state. "Institutions" is the key word here: while ideas did have a role, British legislators, for whom citizenship in any case was hardly a major interest, were probably more interested in producing norms coherent with existing institutions, rather than norms coherent with general political philosophies. I should also underline here that I consider these institutional differences to be autonomous from what has been described in the area of later minority policies, as the difference between a "multicultural" Britain and an "universalistic republican" France. Not only have these differences often been exaggerated, if one looks at the actual policies in the two countries, ${ }^{6}$ but countries far more "multicultural" than Britain (especially outside Western Europe) have and have 
had citizenship laws that are much more binary than the British ones. While it might appear that articulated definitions of belonging and multiculturalism go hand in hand, the particularity of British citizenship that I explore in this article is much more circumscribed and path-dependent, as I will show in the following paragraphs.

\section{Codifying and convergence} status of the population of the British Empire. As anticipated at the beginning of this article, the 1948 law is notable for defining six separate statuses: citizen of the UK and colonies (CUKC), citizen of independent Commonwealth country (CICC), British subject in Ireland, British subject without citizenship (BSWC), British protected person (BPP) and alien. The Act brought together lesser statuses used for colonial populations (BSWC, BPP) with statuses created as a response to the independence gained by parts of the Empire (Ireland and to a different degree, Canada). A survey of the citizenship legislation of European countries made in the important EUDO Citizenship database (www.eudo-citizenship.eu) does not show laws as complex as the British 1948 Act, ${ }^{7}$ nor are there comparably complex laws among those presented in the analysis of laws of African states of Manby (2010), except for the extreme and hardly comparable case of apartheid South Africa after 1970 (see Klaaren).

Randall Hansen clearly shows how the motivation for introducing the 1948 Act was the creation of a specific Canadian citizenship in 1946 (see also Paul 14-18). With one of the British dominions introducing a specific citizenship, the British Government tried to reconcile this innovation with the conservation of a juridically united Empire (which thus continued to influence the institutions of the metropole - cf Thompson). The United Kingdom was the only Empire to have had white majority dominions such as Canada, Australia and New Zealand; as such, the law can partially be explained by the complex structure of the British Empire and by a greater political will to keep links with at least part of its colonial subjects. Karatani, for example, claims that the whole "fuzziness" of British citizenship derives from a historically constant will to extend some kind of membership beyond Britain (or earlier, England) proper. Still, other explanations are to be found outside strictly colonial factors. No other major colonial power managed the end of its Empire as did Britain: France and Portugal both shed the populations of their colonies from allegiance once the colonial wars were lost, leaving preferential naturalization procedures in place for the colonial elites (white or otherwise) who wished to become full citizens of the metropolitan state. The Netherlands had given Dutch nationality to the population of its smaller Caribbean colonies, while limiting conferring the lesser status on the majority of the much larger population Indonesia. Despite this differentiation, most of the colonial population was pushed to renounce Dutch nationality on independence (see Van Oers et al.). As suggested up until now in this article, introducing such a complex law as the BNA of 1948 was more feasible in the United Kingdom than elsewhere, because of the nature of UK institutions. These phenomena are better explained by path dependency and/or institutional inertia than by the strength of ideas; in fact, the relationship of the British governments to the populations of its former colonies during decolonization has been described by several commentators as strongly ambiguous (see, among others, Freeman \& Spencer; Solomos et al.; Miles \& Phizacklea; Paul). 
17 Hansen (op. cit.) observes how the 1948 Act seems out of place considering how the right of entry of colonial subjects began to be limited a few years after the Act, but he explains how this immigration channel became a central issue only in the 1950s. The 1962 and 1968 Commonwealth Immigration Acts signalled the closing of opportunities for entering Britain that had theoretically been available up to that point. Before the 1960s, there were limitations on free movement between different parts of the Empire, in particular on movement to the white majority dominions (see also Banerjee), while Britain itself was theoretically open to all subjects of the Crown. The Commonwealth Immigration Acts limited this freedom and did so in ways reminiscent of previous measures enacted in the white Dominions. The Commonwealth Immigration Acts have been described as implicitly racial in public discourse since the late 1960s, as the full right of entry was restricted to the descendants of people born in the United Kingdom, while limiting the right of entry for other colonial subjects. This implicitly meant leaving space for the "return" of white colonials, while limiting non-white immigration. The 1971 Immigration Act made the approach more explicit by the introduction of the "patrial" category, in reference to individuals descending from people born on UK territory. The Act also made British nationality even more complex and stratified, as the six categories of 1948 were transformed into what can be considered ten separate statuses, with CUKCs, CICCs, BSWCs and Irish citizens being divided between patrials and non-patrials.

1981 saw further restrictions being imparted on the right to entry of several categories, but also what can be considered the start of a convergence to the model "of French origin". The 1981 British Nationality Act further limited the rights attached to certain statuses and made some of the statuses (British Overseas Citizens - who before were non-patrial CICCs, British subjects-former non-patrial BSWCs, and BPPs) non-passable to one's offspring. While the main intention and meaning of the act was again to limit the possibilities for colonial subjects to enter the metropolitan territory, making part of the statuses destined to extinction meant a potential simplification of British nationality.

While British nationality still has not reached the citizen/non-citizen binary simplification, in a number of aspects it has become more similar to other European citizenship laws. Karatani underlines how the entire 1962 to 1981 period can be considered as having been characterized by the "nationalization" of British citizenship. This convergence with the binary model often happened by way of imitating the more restrictive measures of other European states, as with the 2002 and 2009 reforms that saw naturalization tests take a restrictive direction (see, among others, Kostakopoulou) that echoed the spread of naturalization tests across Europe since the late 1990s. More generally, some statuses have been hollowed out of content by the restriction of access to metropolitan territory, with some statuses having been made almost vestigial. There are still measures in Britain that are not so common in other states, such as the right of Commonwealth and Irish citizens to vote in national elections without having to obtain British citizenship. Nonetheless, British laws today are not as dissimilar from those of the rest of the world as they were some decades ago, even if this change occurred mostly by way of the introduction of restrictive measures. 


\section{“Everyday citizenship" implications}

20 The arguments presented up to now have dealt with institutional tendencies that are retraceable through historical periods and at a high level of abstraction. Considering how Brubaker's work on citizenship in France and Germany (1992) has often been taken as indicating different orientations of French and German societies as a whole, ${ }^{8}$ it is important to highlight here that legislation on, and everyday social conceptions of citizenship, have no strong deterministic link.

21 "Everyday citizenship" is an approach that uses qualitative methods to study the conceptions that common people have of citizenship (see Miller-Idriss 2006; Fox \& Miller-Idriss). Other than being obviously variable from one person to the next, these conceptions are also fairly autonomous from those expressed in the laws of a given state. For example, while Germany and Italy are considered to have restrictive and "ethnic" citizenship laws, Miller-Idriss's research with young people in Berlin (2006), as well as my own research with Italian factory workers in the Ferrara area (Sredanovic), show the predominance of, respectively, inclusive cultural conceptions, and inclusive economic conceptions of citizenship. Moreover, everyday conceptions seem to be less inertial and path-dependant than legislation: in the same Berlin research, Miller-Idriss (2009) shows significant changes in terms of ideas of nationality between the generation of teachers she interviewed and the generation of their students.

If the main result is the relative autonomy of laws and everyday visions, there is nevertheless a traceable result of the French-British divergences presented up until now. The Leicester research of Lister, Smith and colleagues (Lister et al.; Smith et al.) on the perceptions of citizenship by young people found a rather vague idea of citizenship, some of the interviewees having being unable to define it, or stating simply that "everybody is a citizen" (Lister et al. 237). On the other hand, a number of studies with young people in France (Venel; Ribert; Rio) and again, Miller-Idriss' research with young people in Germany (2009), found ideas of citizenship that, without being completely free of misconceptions, nevertheless showed much greater clarity than the Leicester one. It could therefore be hypothesized that the shorter and less defined history of citizenship in Britain has led to a less diffuse social sedimentation of the concept. The different ideas about what makes someone a citizen according to the Leicester interviewees - for example the fact of being "respectable", i.e., the idea of being employed and having a family - were also found among the interviewees of other research, the differences between the different studies being the level of clarity that the concept of citizenship in general assumes.

Obviously, the historical development of the concept is not the only possible determinant for its clarity among ordinary people. For example, among the Italian factory workers I interviewed (Sredanovic), many did not distinguish between citizenship as such and more limited statuses such as a permit of stay. Other factors, such as the salience of citizenship legislation within public political debate, or citizenship education, can be as influential as the historical development of the legislation. ${ }^{9}$ In this sense, the rising importance given to citizenship in education and in other British policies since the 1998 Crick Report (see Kiwan) is probably having an impact on the social salience of citizenship in Britain, which might become more visible in the next few years. Still, these policies remain characterized by an approach that puts forward social cohesion and neoliberal norms of citizen responsibility. These 
approaches to citizenship, citizenship education and citizenship policy are not uncommon in other countries, nor have they been absent in the past outside Britain. Nonetheless, rights and political participation in Britain have comparatively less institutional expression where they have been explicitly linked to citizenship. I do not wish to exaggerate the implications of these developments here; British society has not been less concerned with rights and participation than other societies and the most famous academic codification of citizenship-as-rights (Marshall) remains British. Still, the effects of historical and institutional definitions of citizenship in Britain are probably worth exploring.

\section{Conclusions}

In this paper, I have shown how citizenship in Britain in its external and formal dimensions has been set apart from most other states due to lesser systematicity, late codification and higher complexity. These original characteristics are linked to a large number of causes, including the general juridical (common law) system, political history (lack of popular revolutions), the different nature of British political rights (based on limitations imparted on state powers), colonial history, institutional equilibrium and path dependency.

It was also my intention to emphasize that, despite the multiplicity of factors involved, the impact of the nature of citizenship in Britain should not be exaggerated, as the differences in everyday perceptions between Britain and other contexts are mostly limited to the salience, rather than on the content, of citizenship. More generally, the effects which seem to depend more on "institutional" (i.e., historical forms of citizenship) than on "material" (e.g., the colonial situation) factors, are probably best explained in terms of path dependency and institutional inertia. To attribute it entirely to concepts such as universalism or liberalism would likely mean exaggerating the strength of ideas.

Studies, such as the present one, that compare general institutions across different countries and ample periods of time should always be conducted with caution. First, they need ample comparable data. In the case of citizenship legislation, this data exists especially for Europe (although the EUDO Citizenship project has started including data beyond Europe). Data covering other countries and offering more detail on the historical evolution of legislation, would allow a better understanding of the themes discussed here. Moreover, studies based on time periods that are large in scope, as well as on general themes, often tend to generalize their findings and to attribute them great explanatory and causal force, only to often be contradicted by studies more limited in themes, time and space.

Nevertheless, it is my hope that in this paper, I have shown the existence of limited phenomena, such as the British approach to citizenship at the end of the colonial Empire and the lesser social salience of the concept of citizenship among young people in Britain as aspects that can or need be explained (also) by institutional factors. 


\section{BIBLIOGRAPHY}

Anderson, Benedict. Imagined Communities. Reflections on the Origin and Spread of Nationalism.

London: Verso, 1991.

Banerjee, Sukanya. Becoming Imperial Citizens. Indians in the Late-Victorian Empire. Durham, NC.

Duke University Press, 2010.

Brubaker, Rogers. Citizenship and Nationhood in France and Germany. Cambridge, MA.: Harvard University Press, 1992.

--- “The Manichean Myth: Rethinking the Distinction between 'Civic' and 'Ethnic' Nationalism." In Nation and National Identity. The European Experience in Perspective, Eds. Hanspeter Kriesi et al. Chur: Rüegger, 1999. 55-72.

Colley, Linda. Britons: Forging the Nation 1707-1837. New Haven: Yale University Press, 1992.

Donati, Sabina. A Political History of National Citizenship and Identity in Italy, 1861-1950. Stanford, CA.: Stanford University Press, 2013.

Dummett, Ann. "United Kingdom.", In Acquisition and Loss of Nationality. Policy and Trends in 15 European States. Eds. Rainer Bauböck et al. Amsterdam: Amsterdam University Press, 2006. 551-585.

--- \& Andrew Nicol. Subjects, Citizens, Aliens and Others. Nationality and Immigration Law. London: Weidenfeld and Nicolson, 1990.

Favell, Adrian. Philosophies of Integration. Immigration and the Idea of Citizenship in France and Britain. Houndmills: Palgrave, 1998.

Fox, Jon \& Cynthia, Miller-Idriss. “Everyday nationhood.” Ethnicities 8:4 (2008): 536-563.

Freeman, M.D.A. \& Sarah Spencer. "Immigration Control, Black Workers and the Economy." British Journal of Law and Society 6:1 (1979): 53-81.

Hansen, Randall. “The Politics of Citizenship in 1940s Britain: The British Nationality Act." Twentieth Century British History 10:1 (1999): 67-95.

Hobsbawm, Eric J. Nations and nationalism since 1780. Programme, myth, reality. Cambridge: Cambridge University Press, 1992.

Holt, James Clarke. Magna Carta, Cambridge: Cambridge University Press, 1992.

Karatani, Rieko. Defining British Citizenship. Empire, Commonwealth and Modern Britain, London: Frank Cass. 2003.

Kiwan, Dina. "Learning to be 'British'? Education and Naturalization in the UK.", In Naturalization Policies, Education and Citizenship. Multicultural Societies in International Perspective, Ed. Id. Houndmills: Palgrave, 2013. 25-49.

Klaaren, Jonathan. "Post-Apartheid Citizenship in South Africa." In Citizenship Today. Global Perspectives and Practices. Eds. T. Alexander Aleinikoff \&Douglas Klusmeyer. Washington, D.C.: Carnegie Endowment for International Peace, 2001. 221-252.

Knop, Karen. "Relational Nationality: On Gender and Nationality in International Law." In Citizenship Today. Global Perspectives and Practices. Eds. T. Alexander Aleinikoff \& Douglas Klusmeyer. Washington, D.C.: Carnegie Endowment for International Peace, 2001. 89-124. 
Kostakopoulou, Dora. "Matters of Control: Integration Tests, Naturalisation Reform and Probationary Citizenship in the United Kingdom." Journal of Ethnic and Migration Studies 36:5 (2010): 829-846.

Lister, Ruth et al. "Young People Talk about Citizenship: Empirical Perspectives on Theoretical and Political Debates." Citizenship Studies 7:2 (2003): 235-253.

Manby, Bronwen. Struggles for Citizenship in Africa. London: Zed Books, 2009.

--- Citizenship Law in Africa. A Comparative Study. New York: Open Society Foundations, 2010.

Marshall, Thomas H.. "Citizenship and Social Class.”, In Id., Citizenship and Social Class and other essays. Cambridge : University of Cambridge Press, 1959. 1-85

Marx, Karl. La guerre civile en France. Paris : Éditions Sociales, 1972.

Miles, Robert \& Annie Phizacklea. White Man's Country. Racism in British Politics. London: Pluto Press, 1984.

Miller-Idriss, Cynthia. "Everyday Understandings of Citizenship in Germany." Citizenship Studies 10:5 (2006): 541-570.

--- Blood and Culture. Youth, Right-Wing Extremism, and National Belonging in Contemporary Germany. Durham, NC.: Duke University Press, 2009.

Mirow, M.C.. "The Power of Codification in Latin America: Simón Bolívar and the Code Napoléon." Tulane Journal of International and Comparative Law 8:1 (2000): 83-116.

Paul, Kathleen. Whitewashing Britain. Race and Citizenship in the Postwar Era. New York : Cornell University Press, 1997.

Ribert, Évelyne. Liberté, égalité, carte d'identité. Les jeunes issus de l'immigration et l'appartenance nationale. Paris : La Decouverte, 2006.

Rio, Fabienne. Les tribulations identitaires de Franco-Algériens. Représentations et enjeux des nationalités française et algérienne. Codes, laïcité, éducation, football. Paris: L’Harmattan, 2010.

Sahlins, Peter. "The Eighteenth-Century Citizenship Revolution in France." In Migration Control in the North Atlantic World. The Revolution of Practices in Europe and the United States from the French Revolution to the Inter-War Period. Eds. Andreas Fahrmeir et al. New York: Berghahn, 2003. 11-24.

--- Unnaturally French. Foreign Citizens in the Old Regime and After. New York: Cornell University Press, 2004.

Sawyer Caroline \& Helena Wray. "Country Report: United Kingdom.” (November 2012) 10 Nov 2016 < http://eudo-citizenship.eu/admin/?

$\mathrm{p}=$ file\&appl=countryProfiles\&f=United\%20Kingdom.pdf >

Schnapper, Dominique. La communauté des citoyens. Sur l'idée moderne de nation. Paris: Gallimard, 1994.

Smith, Noel et al. "Young People as Real Citizens: Towards an Inclusionary Understanding of Citizenship." Journal of Youth Studies 8:4 (2005): 425-443.

Solomos, John et. al. "The Organic Crisis of British Capitalism and Race: the Experience of the Seventies." In The Empire Strikes Back. Race and Racism in 70s Britain, London: Centre for Comparative Cultural Studies - Routledge, 1982. 7-43.

Sredanovic, Djordje. "Culture or Taxes? The Conceptions of Citizenship of Migrants and Local Factory Workers in Italy." Citizenship Studies 18:6-7 (2014): 676-689. 
Thompson, Andrew. The Empire Strikes Back? The Impact of Imperialism on Britain from the MidNineteenth Century. Harlow: Pearson Longman, 2005.

Torpey, John. The Invention of the Passport. Surveillance, Citizenship and the State. Cambridge: Cambridge University Press, 2000.

Van Oers, Ricky, Betty De Hart \& Kees Groenendijk. "The Netherlands.", Acquisition and Loss of Nationality. Policy and Trends in 15 European States. Eds. Rainer Bauböck et al. Amsterdam: Amsterdam University Press. 391-434.

Venel, Nancy. Musulmans et citoyens. Paris: PUF, 2004.

Wright, Sue. "French as a Lingua Franca." Annual Review of Applied Linguistics 26 (2006): 35-60.

\section{NOTES}

1. Citizenship and subjecthood are here considered as institutions - as patterns of norms that exist in relatively comparable forms across time and legal systems. This allows both to discuss the two without limiting oneself to the individual laws as they were promulgated, and to treat the French and British models of citizenship as heuristically different institutions.

2. Historically the distinction in France between nationalité and citoyenneté has been among the clearest distinctions between the juridical status that links an individual and a state (the external dimension of citizenship, nationalité) and the rights, especially political rights, linked to this status (the internal dimension of citizenship, citoyenneté). However, the two institutions are never easy to completely distinguish, and there is no vocabulary that clearly identifies the two dimensions across countries and time. In this article, the focus is on the external dimension of citizenship - that for which Britain is set apart - but I will nonetheless use both concepts of citizenship and nationality, reserving the second term for notions of citizenship less linked to (political) rights.

3. Holt is a good synthesis of both the positions that see the Magna Carta as the closest thing to a Constitution that exists in the United Kingdom, and the positions that see it as establishing merely feudal privileges similar to those existing elsewhere in Europe at the time.

4. Dummett \& Nicol 1990, 59-63. I will not expand on the details of the different laws in this article, as excellent histories of the British citizenship legislation exist already - other than Dummett \& Nicol, see Dummett 2006 and Sawyer \& Wray 2012. I will rather focus on the aspects that set Britain apart from the most common ways in which the other states have regulated citizenship.

5. Colley links this development, and the extension of suffrage in 1832, to the military mobilization of a large part of the male population during the war against Revolutionary and Napoleonic France, and the consequent need to recognize a larger part of the population as citizens.

6. But see the more articulated analysis of Favell.

7. Several states, such as Germany, Greece, or Hungary, do have something similar to a specific juridical status for "co-ethnic" non-nationals, but these are arguably used to facilitate naturalization or assure specific rights, rather than intended to be permanent membership statuses.

8. This has been criticized by the author himself: see Brubaker 1999.

9. The knowledge of citizenship of the students interviewed in Miller-Idriss 2009 is not so surprising considering that during the research of the author they were receiving classes on citizenship and citizenship laws. 


\section{ABSTRACTS}

In this article I offer an analysis of the history of citizenship in the UK by showing the low level of systematicity and the high complexity of this institution. By comparing it with the binary French case, I consider the two models of citizenship as two institutions with different goals, arguing that the diffusion of the French model has turned British citizenship into an insular case. I further show that the consequences of the different histories of citizenship can be found in everyday conceptions of citizenship in the UK and elsewhere, but that these consequences are limited to the salience and not to the content of the concept.

Dans cet article je propose une analyse de l'histoire de la citoyenneté au Royaume-Uni. En le comparant au cas français, de nature binaire, je propose une approche des deux modèles de citoyenneté en tant qu'institutions ayant différentes finalités, en soutenant que la diffusion du modèle français a rendu insulaire le modèle britannique de citoyenneté. Je montre également que l'on trouve les conséquences de ces histoires différentes dans les conceptions quotidiennes de la citoyenneté au Royaume-Uni et ailleurs, mais que ces conséquences sont limitées à l'importance relative du concept, et non à son sens-même.

\section{INDEX}

Mots-clés: citoyenneté, nationalité, législation, Royaume-Uni, France

Keywords: citizenship, nationality, law, United Kingdom, France

\section{AUTHOR}

\section{DJORDJE SREDANOVIC}

Postdoctoral fellow

Group for research on Ethnic Relations, Migration \& Equality/Migrations Asylum

Multiculturalism/Université Libre de Bruxelles

djordje.Sredanovic@ulb.ac.be 